\title{
Problem of Truth in Historiography
}

\author{
Alexander Nesterenko \\ Bauman Moscow State Technical University \\ 5/1, 2nd Baumanskaya St. \\ Moscow, Russia 105005 \\ E-mail: rockwool@list.ru
}

\begin{abstract}
From its very beginning, history was regarded as rational and scientific knowledge objectively reflecting historical reality. Such ideal definition of the past has no fundamental epistemological foundation and is not based on the concepts of the classical scientific rationality, since historiography does not comply with any of the existing concepts of truth. The author concludes that none of the scientific criteria of truth can be applied to recounting the past. Conclusion can be made that claims of historiography for truth are not justified. Historical narrative cannot be true or false, it can only be consistent or inconsistent with the source. Historiographical constructs are ontologically subjective and biased preventing us from restoring the past as a whole picture without speculative assumptions. Thus, from epistemological point of view, scientific knowledge about the past is impossible.
\end{abstract}

Keywords-truth; truth criteria; science; history; historiography; epistemology; narrative; "we-group"

\section{INTRODUCTION}

Science aims to search for truth, i.e. knowledge most corresponding to reality. Since Herodotus times, historians have been trying to legitimize their scientific status, claiming to be true and objective. Lucian of Samosata when arguing "how to write history" insisted that a historian should care not for the beauty of the words but "establish truth". Lucian suggested that historians should rely on their intuition to determine which evidence is more trustworthy. Historiography does not have scientific methods to determine the truth of judgements [1].

Historians admit that, similar to poets and writers, they create a narrative, but they claim that unlike storytelling this narrative is a reliable description. Leo Tolstoy strongly disagreed with this position writing about "the inevitably false description of historical events by historians". Tolstoy proved this statement by explaining that history is written based on documents for instance, military reports where the events are described with "the boasting lies essential in this business" [2]. Tolstoy states that nobody, even participants of events can know what had actually happened therefore historians create imaginary description of the past [3].

Tolstoy believes history to be a sum of memories. This approach does not solve the epistemological problem of establishing the truth of the concept of the past.

Scientific truth can only be a posteriori i.e. it must exist not only as theory (or memories, in the case of history).
Consequently, truth of theory or fact must be verifiable in practice, for example, experimentally. In science, truth of theory is verified by experiment comparing a thought with its real object. In the case of recounting the past such procedure is impossible because the past does not exist as object. Therefore, our ideas about the past "can never be verified as we verify our scientific hypotheses" [4]. The reference of the description is not an object but another description.

\section{ClassicAl CONCEPTION OF TRUTH IN HISTORIOGRAPHY}

If in a classical epistemology sense, truth is the correspondence between knowledge and reality, while for historiography the reality is text, this formula will look like correspondence between knowledge and source. Establishing the veracity of an event in the past can only be done by comparing one source with another one and (or) with a combination of statements describing what happened before and after the event. Verification and falsification in historiography are always within the text framework.

To verify a past event the source must be compared with a non-linguistic reference. Since it is impossible, the source can only be compared with itself or other sources describing the same events or (which is equally important) failing to mention them. However, it raises the question regarding the source reliability. In epistemology this problem is unsolvable because "we can never compare the actual past to the statements the historian has made about it" [5]. Therefore there is no objective criterion to measure the correspondence between the description of the past and the past itself. As a result, everything a historian considers true is true. The criterion of truth in historiography is the historian himself [6] Consequently, the classical correspondence criterion cannot be applied to historiography. What is possible in historiography is establishing the correlation between several semantic systems: sources and their historical narrative. Scientific truth is general in its nature and, consequently, is independent from a subject's opinion. Unlike the subjective ideas about the past, the objectivity of scientific knowledge helps reveal the falsehood [7].

The source is the only thing the historians can compare their statement against. But what can be done when there are several sources all claiming the opposite? Which of them to choose and what should historian be guided by? The answer to this question is obviously to choose the most reliable 
source. However, there are no objective criteria to do this. Ultimately, the historians decide themselves which source (not) to use, i.e. this choice is subjective. Even if several sources give the same accounts of a certain event, there are no reasons to take it for a scientific fact. While the correspondence between knowledge and facts is an attribute of scientific knowledge and its truth criterion, the only thing to say about truth in historiography is that certain events had been recorded on the space-and-time scale.

\section{CONVENTIONAL CONCEPTION OF TRUTH IN HISTORIOGRAPHY}

The ontological equality between the past and nonexistence must lead to the fact that in history the object of research exists only in the historian's consciousness, i.e. they are inseparable: "the historian is an integral element in the process of history itself, reviving in himself the experiences of which he achieves historical knowledge" [8]. The same event can be interpreted from different points of view and all these different points of view will be equally true, consistent with one another. Any reconstruction of the past is subjective and Protagoras' dictum that "man is the measure of all things" can be applied to it [9]. Therefore, historiography is a continuum of multiple opposing opinions, each of them equally verifiable, which leads to antinomies based on the sources arbitrarily interpreted by historians.

A logically inconsistent interpretation of the past in historiography is predicated by the fact that historians relate themselves to different identities. As an example let us take the Russian historiography which is traditionally dependent on the prevailing ideology. For example, Bishop Albert, the founder of Riga, is presented extremely negatively in the Russian historiography. However, there is no source to confirm this. In the Livonian Chronicle of Henry entirely devoted to his work, Albert is described as an outstanding historical figure [10]. While father of Alexander Nevsky, Prince Yaroslav Vsevolodovich, despite the information in sources, in presented as a positive character in the Russian historiography [11].

Even if the historians aspire to be objective and only state the facts; the facts description complies with the narrative logic and their selection is determined by the researcher's viewpoint. Historiography cannot be restricted to simple facts: this cannot help understand the meaning of events [12]. Everything beyond the facts is interpretation which is determined by the personality of the narrator. Consequently, in historiography the non-contradiction of knowledge is impossible. The coherence criterion of truth is inapplicable.

The attributive subjectivity of historiography results in the relativity of ideas about the past, which leads to the fact that content of any reconstruction of the past is determined by its creator's standpoint. Therefore, every historian reconstructs the past differently and this relativity can never be overcome because there is no method to do it [13]. As a result, different reconstructions of the past interpret, rather than recount the facts or events. Reconstruction of the past is always a palliative: the text is a subjective sequence of facts determined by the author's will [14].
However, unlike scientific facts that are objective reality, historical facts exist only as semantic reality. The historian learns about the past events indirectly through narrative sources. Consequently, in historiography there are no facts in a scientific sense but there are some events described in sources and artefacts which historians classify as facts. Social reality is not narrative: it becomes one only when recounted. Narrative, in its turn, is not reality but only one of the many possible stories about what has happened [15].

Since sources, as basis for the construction of the historical facts, are nothing more than a subjective narration of the past events, historiography is a classical simulacrum: narrative source becomes the subjective object of speculation by the researcher professing scientific objectivity. However, this objectivity is subjective in its nature: instead of the critical analysis it is based on the author's assessment of the past based on patriotism, nationalism, religion and other values and mental features [16]. As a result, instead of science we get value judgements determined by the author's personality.

In this sense, historiography is a speculative construct and its entire content is only true within one narrative and false within another. Unlike scientific facts, historical facts are ontologically subjective and only conventionally true as a result of some authors' agreement. However, as opposing interpretations of the past result from a clash of values, compromise between them is impossible. A single intersubjective history does not exist but there is a multitude of narrative representations of the past, every of them reflecting the need for "we-groups" to identify 'us' versus 'them'. None of the groups holds the exclusive right to truth. Consequently, the convention concept of truth cannot be applied to historiography because there are no concepts shared by all historians and they are impossible.

Still another ontological problem of historiography does not permit epistemological criteria of truth. It is that history always deals with something single and accidental: unlike science, which deals with something general and universal [17]. History describes only unique events, which, even when similar to other events, stay unique. Consequently, historiography does not describe and does not explain the essential universal causality and is different from science in this respect. It was Aristotle who discovered this feature of the past assumptions claiming that "poetry is more philosophical and serious than history. For poetry speaks more of universals, but history of particulars" [18].

\section{THE PROGMATIC CONCEPTION OF TRUTH IN HISTORIOGRAPHY}

That is the reason why the pragmatic criterion of truth cannot be applied to the knowledge about the past. The present offers new challenges which cannot be solved with the past experience: "but what experience and history teach us is this - that nations and governments have never learned anything from history...Each age and each nation finds itself in such peculiar circumstances, in such a unique situation, that it can and must make decisions with reference to itself alone" [19]. It can be stated as a fact that no historical study 
has ever influenced the present. If it had, for instance in the $20^{\text {th }}$ century, there would not have been the two World Wars. In reality, humanity has learned no lessons from history since Herodotus and Thucydides' times, repeating their mistakes for centuries and centuries. We should admit that historical research, far from influencing the present, uses the past in its interests interpreting it the most advantageous way for this particular moment.

It can be said that views about the past are neither truths of reason being logically controversial, neither they are truths of fact as they are not obtained empirically. It is impossible to state what fiction is and what reality is because the sources outside the semantic reality cannot be verified. Consequently, our views about the past do not comply with the epistemological criteria of truth. They are trusted, same as axioms or religious dogmas. Historians randomly choose from a pool of evidence the proof that seems reliable and transform it into historical facts ignoring the evidence that does not fit into the theoretical construct [20]. Being confident that this evidence is real becomes the criterion of truth. At best, historians follow Herodotus' advice and report events no matter if they consider them true or real [21].

Historiography is selective and biased, always a response of a concerned person with a certain standpoint [22]. Views about the past cannot be reliable since they are based on fragmentary evidence that the previous generations decided to preserve for the descendants. These views always reflect a certain viewpoint and contain only the facts that support this viewpoint. The past evidence tends to be fragmented and historians have to combine them into a holistic picture of the past based on hypothetical views while the true connection of events may be even for contemporaries and participants. Nietzsche identified three types of history: monumental, antiquarian and critical [23]. The first is practically the same as ideology; the second is a collection of historical anecdotes; the third is speculative assumptions about what could have happened which are impossible to verify save for the strength of the author's argumentation.

\section{CONCLUSION}

Since "there can be no history of "the past as it actually happened' there can only be historical interpretations, and none of them final; and every generation has a right to frame its own. But not only has a right to frame its own interpretations, it also has a kind of obligation to do so; for there is indeed a pressing need to be answered" [24]. In this case, the only criterion of truth in historiography is the correspondence between the narrative and the "we-group" self-identity. The criterion of truth in historiography is not verity (as in science) but correctness understood as conforming to the "we-group" vision of the past. This vision should serve a source of pride for the "we-group" and the foundation for the "us versus them" identity.

All narratives not conforming to the "we-group" perceptions about the past will be considered as false. Consequently, the main criterion of truth in historiography is its relevance, i.e. the interpretation of the past which are advantageous at a given moment. But this criterion of truth is not scientific. Therefore, historiography since its early days has not contributed to the acquisition of true knowledge having become the instrument of mass consciousness manipulation in the interests of the establishment.

\section{REFERENCES}

[1] Lucian de Samosata. Selected dialogues. OUP Oxford, 2005.

[2] L. Tolstoy. Some words about "War and Peace". Collected works in 22 volumes. Moscow, Khudozhestvennaya literatura, 1981, vol. 7, pp. 356-366. P. 361 .

[3] B. Croce. Theory history of historiography. Fb\&c, 2017, p. 34

[4] R.G. Collingwood. The idea of history. OUP Oxford, 1994, p. 9.

[5] F.R. Ankersmith. History and tropology: the rise and fall of metaphor. University of California Press, 1994, p. 84.

[6] R.G. Collingwood. The idea of history. P. 137.

[7] N.I. Gubanov, N.N. Gubanov. Subjective reality and space // Voprosy filosofii. 2015. № 3. P. 45-54.

[8] R.G. Collingwood. The idea of history. P. 164.

[9] Diogenes Laërtius. Lives of Eminent Philosophers. Harvard University Press (Cambridge/London), 1925, p. 463.

[10] A.N. Nesterenko. Bishop Albert // Voprosy istorii. 2015. № 3. P. 5068.

[11] A.N. Nesterenko. Yaroslav Vsevolodovitch // Voprosy istorii. 2014. № 11. P. 31-47.

[12] B.N. Zemtsov. Discussion about the Essence of the Proletarian State in the CPSU between 1919 and 1923 // Izvestia Ural Federal University Journal. Series 2. Humanities and Arts. 2016. Vol. 151. № 18 (2). P. 57-68.

[13] R. Aron. Introduction to the philosophy of history: an essay of the limits of historical objectivity, Beacon Press, 1961, p. 289.

[14] A.N. Nesterenko. The false narratives of the Alexander Nevky's biography in Russian historiography // Voprosy istorii. 2016. № 1. P. $103-114$.

[15] V.A. Nekhamkin. A counterfactual Challenge of the Past: Ways of Negotiation // Herald of the Russian Academy of Sciences. 2017. Vol 87. Issue 2. P. 191-198. DOI: 10.1134/S1019331617020046

[16] N.I. Gubanov, N.N. Gubanov. Mentality: the nature and functioning in society // Voprosy filosofii. 2013. № 2. P. 22-32.

[17] B.N. Zemtsov. Right as World Outlook Value of the Power (XX Century) // Tomsk State university journal of history. 2014. № 4 (30). P. 28-34.

[18] Aristotle. Poetics, Hackett Publishing, 1987.

[19] G.W.F. Hegel. Lectures on the philosophy of world history, Cambridge University Press, 1980, p. 21.

[20] A.N. Nesterenko. Teutonic Order in the war 1240-1242 period // Voprosy istorii. 2014. № 8. P. 146-152.

[21] Herodotus, with an English translation by A. D. Godley. The Histories, Cambridge, Harvard University Press, 1920.

[22] M. Oakeshott. Activity of being a historian// What is history?: and other essays, Andrews UK Limited, 2011.

[23] F. Nietzsche. Untimely Meditations, Cambridge University Press, 1997.

[24] K.R. Popper. The open society and its enemies. Vol. 2, Rouledge Classics, 2002, p. 255. 